Egyptian Journal of Rabbit Science, 27 (2): 359- 375(2017)

\title{
EFFECT OF FEED RESTRICTION SYSTEM ON PERFORMANCE, CARCASS TRAITS, MEAT QUALITY AND BLOOD PARAMETERS OF GROWING RABBITS
}

\section{E. Abou-Kassem}

Poultry Department, Faculty of Agriculture, Zagazig University, Zagazig, Egypt.

The objective of the present study to investigate the effect of feed restriction system on growing performance, carcass traits, meat quality and blood parameters of growing New Zealand White (NZW) rabbits, during experimental periods from 5 to 13 weeks of age. A total number of $90 \mathrm{NZW}$ rabbits (male and female ratio 1:1) of weaning aged 5 weeks (about 777.45 $\pm 10.38 \mathrm{~g}$ body weight) were randomly divided into five experimental groups $(n=18$ each), the first group was fed ad-libitum as control, the second group was fed restriction a mount of feed for first 2 weeks only, the third group was fed restriction for 4 weeks only, the fourth group was fed restriction 6 weeks only and the fifth group was fed restriction for all experimental period (8weeks).

Results showed a significant $(P<0.01)$ increased of live body weight, weight gain and feed intake in group 1 (ad libitum) as compared with other restricted groups. No significant effect was observed in health status or mortality percentage of rabbits during experimental periods.

Renal fat was significantly $(P<0.05)$ reduced in rabbits restricted as compared with control group. The meat $\mathrm{pH}$ was not affected by restriction feed groups. On the other hand blood parameters studied were not significantly influenced by the treatment.

Conclusively, it could be concluded that, feed restriction groups of growing rabbits at different ages studied with various mounts can be adopted because it does not interfere negatively in the performance, meat quality and blood parameters. Also it's beneficial in improvement of feed and economic efficiencies.

Key words: Feed restriction, performance, carcass traits, meat quality, blood parameters, growing rabbits. 
Feeding is the main cost in rabbit production, so the control of feed intake could be used to adjust the diet and nutritional requirements to manage the growth performance (Yakubu et al., 2007; Bergaoui et al., 2008).

In commercial farms, growing rabbits are usually fed ad libitum (Maertens, 2009). However, feeding can be restricted during the post-weaning period to improve feed efficiency and standardize growth curves in rabbits with a different feed ingestion level (Ouhayoun et al., 1986; Cavani et al., 1991) or to control the appearance of digestive disorders (Gidenne et al., 2009 and 2011).

The application of feed restriction during fattening period of rabbits, without compromising too much the growth, may be a good strategy for rabbit management, because it may decrease the feeding cost and reduce the health risk (Gidenne et al., 2003; Foubert et al., 2008). However, inadequate and high cost of feed ingredients brought about mainly by the stiff competition between man and monogastric animals such as rabbits and poultry for grains is the major constraint to rabbit production (Agunbiade et al., 2002).

The early-life fast growth rate in rabbit is accompanied by a number of problems, namely increased body fat deposition, high incidence of metabolic disorders, high mortality, and high incidence of skeletal diseases. In the growing rabbits, an early feed restriction applied around post-weaning age could be of interest to improve feed efficiency (Tumova et al., 2002; Tumova et al., 2003; Yakubu et al., 2007; Gidenne et al., 2009 and Gidenne et al., 2012), to induce compensatory growth (Tumova et al., 2002; Foubert et al., 2008), to reduce carcass fat deposition (Tumova et al., 2004), to improve digestibility of nutrients during the restricted feeding period (Tumova et al., 2004 and Di Meo et al., 2007).

Feed restriction suppresses growth during the restriction period, but the growth reduced can be compensated with greater future intake (Govaerts et al., 2000). Nevertheless, feed restriction can be used at different periods (usually from one to three weeks after weaning) or at different levels (restriction percentage in order to free intake) (Di Meo et al., 2007).

In fact, digestive disorders are the main cause of morbidity and mortality in growing rabbits which are responsible for important economic losses in industrial rabbit farms (Ebeid et al., 2012). Therefore, early feed restriction could be used a useful tool to improve the biological and economic performance (Tumova et al., 2007), which consequently involved in reducing the costs of production (Yakubu et al., 2007).

Carcass traits of rabbits are not influenced by feed restriction (Ledin, 1984). Tumova et al., (2003) found that feed restriction did not affect on body 
weight or carcass yield for rabbits received restricted feed for three weeks which had lower body weight than the groups restricted for one or two weeks, although yield was not influenced by the feeding regimen.

The gastrointestinal tract is longer in the restricted rabbits, which might explain in part reduction in the carcass yield (Cantier et al., 1969). However, in the growing rabbits, an early feed restriction applied around post-weaning age could be of interest to reduce carcass fat deposition (Tumova et al., 2004).

According to Eiben et al., (2001) and Rommers et al., (2001), feed restriction during rearing of rabbit, followed by a short flushing and delay of first insemination to an older age, seems to present a promising strategy for optimizing body development of young and improving their productivity and longevity.

Recently, Birolo et al., (2016) reported that restriction program, a mild feed restriction (93\% of ad libitum) during the first period improved rabbit health status and reduced environmental pollution in the fattening sector without impairing growth performance, slaughter results and carcass traits.

Since feed restriction had positive impacts in growing rabbits, the objective of the present study was to investigate the effect of feed restriction on growth performance, carcass traits, chemical analysis of meat, some blood parameters and economical efficiency of growing NZW rabbits, during experimental periods from 5 to 13 weeks of age.

\section{MATERIALS AND METHODS}

This experiment was carried out in the Rabbitry farm of Poultry Department, Faculty of Agriculture, Zagazig University, Zagazig, Egypt, during two months of April and May, 2016, which extended for eight weeks ago.

\section{Animals and experimental design:}

A total of 90 New Zealand White (NZW) rabbits (male and female ratio $1: 1$ ) of weaning aged ( 5 weeks) and about $777.45 \pm 10.38 \mathrm{~g}$ body weight were housed in commercial wired cages ( 3 rabbits per cage) with floor space of 0.12 $\mathrm{m}^{2} /$ rabbit under $16 \mathrm{hrs}$ photoperiod daily. Rabbits were randomly divided into five experimental groups ( $\mathrm{n}=18$ each), in 6 replicates each of 3 rabbits.

The first group was fed ad-libitum, (as control), the second group was fed restricted feed with $50 \mathrm{~g} / \mathrm{d} /$ rabbit for two weeks only, the third group was fed restricted feed with $50 \mathrm{~g} / \mathrm{d} /$ rabbit for two weeks and $75 \mathrm{~g} / \mathrm{d} /$ rabbit for two weeks, the fourth group was fed restricted feed with $50 \mathrm{~g} / \mathrm{d} / \mathrm{rabbit}, 75 \mathrm{~g} / \mathrm{d} / \mathrm{rabbit}$ and $100 \mathrm{~g} / \mathrm{d} / \mathrm{rabbit}$ for two weeks each, respectively, while the fifth group 
was fed restricted feed with $50 \mathrm{~g} / \mathrm{d} / \mathrm{rabbit}, 75 \mathrm{~g} / \mathrm{d} / \mathrm{rabbit}, 100 \mathrm{~g} / \mathrm{d} / \mathrm{rabbit}$ and $125 \mathrm{~g} / \mathrm{d} / \mathrm{rabbit}$ for two weeks each, respectively, as shown in Table 1.The rabbit groups were fattened until 13 weeks of age.

Table 1. Experimental design:

\begin{tabular}{|l|l|l|l|l|}
\hline \multicolumn{1}{|c|}{$\begin{array}{c}\text { Age } \\
\text { Treatment }\end{array}$} & $\begin{array}{c}\text { 5-7 } \\
\text { Weeks }\end{array}$ & \multicolumn{1}{c|}{$\begin{array}{c}\text { 7-9 } \\
\text { Weeks }\end{array}$} & $\begin{array}{c}\text { 9-11 } \\
\text { Weeks }\end{array}$ & $\begin{array}{c}\text { 11-13 } \\
\text { Weeks }\end{array}$ \\
\cline { 2 - 5 } T1 & \multicolumn{2}{|c|}{ ad libitum during the experimental periods } \\
\hline T2 & $50 \mathrm{~g} / \mathrm{d} / \mathrm{rabbit}$ & ad libitum & ad libitum & ad libitum \\
\hline T3 & $50 \mathrm{~g} / \mathrm{d} / \mathrm{rabbit}$ & $75 \mathrm{~g} / \mathrm{d} / \mathrm{rabbit}$ & ad libitum & ad libitum \\
\hline T4 & $50 \mathrm{~g} / \mathrm{d} / \mathrm{rabbit}$ & $75 \mathrm{~g} / \mathrm{d} / \mathrm{rabbit}$ & $100 \mathrm{~g} / \mathrm{d} / \mathrm{rabbit}$ & ad libitum \\
\hline T5 & $50 \mathrm{~g} / \mathrm{d} / \mathrm{rabbit}$ & $75 \mathrm{~g} / \mathrm{d} / \mathrm{rabbit}$ & $100 \mathrm{~g} / \mathrm{d} / \mathrm{rabbit}$ & $125 \mathrm{~g} / \mathrm{d} / \mathrm{rabbit}$ \\
\hline
\end{tabular}

\section{Housing, feeding and environment:}

Animals were housed in galvanized wired cages batteries $(60 \times 60 \times 40 \mathrm{~cm})$, in a good natural ventilation through the windows (open housing system), while temperatures ranged between 22 to $35^{\circ} \mathrm{C}$ and humidity ranged between 50 to $65 \%$ during experimental periods. A sixteen hours photoperiod was used. Fresh water was available ad libitum. The rabbits were fattened until 91 days of age. Cages were supplied with feeders and stainless steel nipples for feeding and drinking. All rabbits were observed daily, healthy and clinically free from internal and external parasites, vaccinated against common diseases and kept under the same managerial and hygienic conditions.

The experimental diets were formulated to be iso-nitrogenous $(16.75 \% \mathrm{CP})$ and iso-caloric $(2552 \mathrm{kcal} \mathrm{DE} / \mathrm{kg}$ diet). Rabbits were fed pelleted commercial diets formulated to meet recommended nutrient requirements of rabbits according to N.R.C (1977), and the chemical composition of the basal diet was analyzed according to A.O.A.C (1995) as shown in Table 2.

\section{Measurements:}

Initial body weight, body weights, feed intake, body weight gain and mortality rate were recorded during experimental periods. Weighing was carried out before offering the morning meal. Total body weight gain, daily weight gain and feed conversion were calculated.

At the end of experiment (13 weeks of age), six rabbits from each group (one rabbit from each replicate) after being fasted for 12 hours 
Table 2: Composition and Chemical analysis of the experimental diet.

\begin{tabular}{|l|c|}
\hline Ingredients & Percentages \\
\hline Clover hey (13\% CP) & 24.30 \\
Wheat bran & 29.00 \\
Soybean meal, (44\%CP) & 14.00 \\
Yellow corn & 7.00 \\
Barley grain & 20.20 \\
Molasses & 3.00 \\
Di-calcium phosphate & 1.00 \\
Limestone & 0.70 \\
Mineral-vitamin premix* & 0.30 \\
Salt (NaCl) & 0.30 \\
DL-methionine & 0.20 \\
\hline Total & $\mathbf{1 0 0 . 0 0}$ \\
\hline Chemical composition** & 16.75 \\
\hline Crude protein, \% & 2552 \\
Digestible energy (K.Cal/Kg) & 12.30 \\
Crude fiber,\% & 3.05 \\
Ether extract, \% & 0.95 \\
Calcium,\% & 0.68 \\
Total phosphorus, \% & 0.46 \\
Methionine, \% & 0.70 \\
Lysine, \% & $\mathbf{2 7 5 0 . 0 0}$ \\
\hline Price/ton diet, L.E. *** &
\end{tabular}

* One kilogram of premix contained: Vit A 6000, 000 IU; Vit $\mathrm{D}_{3}, 300,000$ IU; Vit. E. $1000 \mathrm{mg}$; Vit k $2000 \mathrm{mg}$; Vit $\mathrm{B}_{1}, 1000 \mathrm{mg}$; Vit $\mathrm{B}_{2}, 1000 \mathrm{mg}$; Vit $\mathrm{B}_{6}, 1000 \mathrm{~g}$; Vit $\mathrm{B}_{12}$, $10 \mathrm{mg}$; Pantothenic acid, $10000 \mathrm{mg}$; Niacin, $200 \mathrm{mg}$; Folic acid, $1000 \mathrm{mg}$; Biotin, 50 mg; Choline Chloride, 500 mg, Fe, 30000 mg; Mn, 3000 mg; Cu, 2000 mg; I, 100 mg; $\mathrm{Co}, 100 \mathrm{mg} ; \mathrm{Se}, 100 \mathrm{mg}$ and $\mathrm{Zn}, 450 \mathrm{mg}$.

** Analyzed according to A.O.A.C (1995).

*** Calculated according to the price of feed ingredients when the experiment was started.

randomly chosen for slaughter test and chemical analysis of it's meat. Slaughter procedure and carcass quality were carried out as described by Blasco and Ouhayoumn (1996). They were then slaughtered by severing the carotid arteries and jugular veins, skinned and eviscerated for measuring carcass parameters. After the removal of the visceral organs and head, the remaining part was measured as carcass weight and this was later expressed as percentage of the fasted weight to get the dressing percentage (Fielding, 1991). The relative weights of the liver, kidneys, and heart were determined using the formula:

Giblets weight, $\%=$ Giblets weight(wt)/Pre-slaughter weight of rabbit $\times 100$ 
Dressing weight $\%=$ Carcass weight + giblets weight $/$ Pre-slaughter wt $\times 100$

The $\mathrm{pH}$ of Biceps femoris was measured at $1 \mathrm{hr}$ post-mortem and the chemical composition of rabbit meat including crude protein (C.P \%), ether extract $\%$ and ash \% were determined according to A.O.A.C. (2000).

Energy values (E.V) of rabbit meat (Cal/ 100g.) was calculated according to Winton and Winton (1958) equation as follows:

E.V $(\mathrm{Cal} / 100 \mathrm{~g})=$.4.1 (\% Protein $+\%$ Carbohydrates $)+9.3$ (\% Fat $)$.

Blood samples were taken after slaughtering within each group and collected into dry clean centrifuge tubes. Blood plasma was separated by centrifugation at 5500 r.p.m. for 10 minutes and kept in a deep freezer a $\left(-20^{\circ} \mathrm{c}\right)$ until biochemical analysis. ALT and AST were colorimetrically determined using commercial kits purchased from Bio-diagnostic, EGYPT, following the same steps as described by manufactures. However, total protein level was estimated according to Armstrong and Corri (1960), albumin level was estimated according to Doumas et al., (1971). Globulin level values were obtained by subtracting the levels of albumin from corresponding values of total protein.

\section{Economical efficiency (E.E\%):}

Economic efficiency of meat production was calculated from inputoutput which was calculated according to the prices of the experimental diets and body weight gain during the year of 2016. The values of economical efficiency for meat production were calculated according to Heady and Jensen, (1954) as follows:

Economic efficiency $(\mathrm{E} . \mathrm{E} \%)=\mathrm{Net}$ revenue $(\mathrm{L} . \mathrm{E}) /$ Total feed cost (L.E) $\times 100$.

While, the price of experimental diet was 2750 L.E per ton and the price of one kilogram body weight selling was 24 L.E, based on prices of Egyptian market during the experimental period (Spring 2016).

\section{Statistical analysis:}

Data of experiment were statistically analyzed using SPSS (2014) according to Sendcor and Cochran (1982) as the following model:

$$
\mathrm{Yij}=\mu+\mathrm{Ti}+\mathrm{eij}
$$

Where $\mathrm{Yij}=$ he individual observation, $\mu=$ The overall mean, $\mathrm{Ti}=$ The effect of treatments, eij $=$ The experimental error.

Significant differences between treatments means were tested according to Duncan's Multiple test (Duncan, 1955). 


\section{RESULTS AND DISCUSSION}

\section{Growth performance:}

Results in Table 3 showed a significant $(\mathrm{P}<0.01)$ decrease in live body weight of growing NZW with restriction feed during all ages studied, also daily weight gain decreased significantly $(\mathrm{P}<0.01)$ with restriction feed from $5-9$ weeks of age while it was insignificantly from 9-13 weeks of age. These results agreed with (Govaerts et al., 2000 and Bergaoui et al., 2008) who reported that the feed restriction suppresses growth during the restriction period, but the growth reduced can be compensated with greater future intake. These results disagreement with Di Meo et al., (2007) who studied the effects of free feeding and feeding restricted to $900 \mathrm{~g} / \mathrm{d} /$ rabbit of the free intake for growing rabbits from 5 to 12 weeks of age, and observed that there was no difference in the body weight and daily weight gain results.

As presented in Table (3), feed restriction system had no effect on mortality percentages of the growing rabbit and no mortality was detected during the experimental period. These results confirmed several previous studies which indicated that feed restriction did not influence mortality percentage of growing rabbits (Foubert et al., 2008 and Ebeid et al., 2012), Also Gidenne et al., 2012 showed that a more long restriction (for 2 or 3 weeks) of growing rabbits reduced mortality and morbidity from digestive troubles, while in contrast El-Speiy et al., (2015) reported that feed restriction significantly $(\mathrm{P} \leq 0.05)$ decreased mortality rate as compared with the control group (ad libitum).

Results showed a significant $(\mathrm{P}<0.01)$ increase in feed intake of growing NZW with ad libitum group (control) as compared with other restriction ones during all experimental periods studied, while the best results of feed conversion recorded with (T5) group of restriction feed all periods 5-13 weeks of age, (Table 6). These result agreed with Alabiso et al., (2016) who summarized that restriction feed system for a 3-week post-weaning of growing rabbits significantly $(\mathrm{P}<0.001)$ decreased feed intake by $(-22$ to $-24 \mathrm{~g}$ dry matter/day) and gave a lower feed conversion ratio than ad libitum feeding.

\section{Carcass traits:}

As presented in Table 4 dressing weight $\%$, significantly $(\mathrm{P}<0.01)$ increase by feed restriction as compared with ad libitum feed and the highest value was recorded with T2 (restricted feed from 5-7 weeks of age only), where carcass \% was not influenced with treatments. Hind part weight $\%$, recorded a high $\%$ with restriction feed system of T2 and T3 as compared with ad libitum or long restriction period (T4 and T5). Liver 
Table 3. Live body weight, weight gain and mortality rate $(\bar{X} \pm S E)$ of growing NZW as affected by feed restriction during all experimental periods.

\begin{tabular}{|c|c|c|c|c|c|c|c|c|c|c|c|}
\hline \multirow[b]{2}{*}{$\begin{array}{l}\text { Traits } \\
\text { Treatment } \\
\text { groups }\end{array}$} & \multicolumn{5}{|c|}{ Live body weight } & \multicolumn{5}{|c|}{ Daily weight gain } & \multirow[t]{2}{*}{ MR } \\
\hline & $\begin{array}{c}5 \\
\text { wks }\end{array}$ & $\begin{array}{c}7 \\
\text { wks }\end{array}$ & $\begin{array}{c}9 \\
\text { wks }\end{array}$ & $\begin{array}{c}11 \\
\text { wks }\end{array}$ & $\begin{array}{c}13 \\
\text { wks }\end{array}$ & $\begin{array}{c}5-7 \\
\text { wks }\end{array}$ & $\begin{array}{c}\text { 7-9 } \\
\text { wks }\end{array}$ & $\begin{array}{l}9-11 \\
\text { wks }\end{array}$ & $\begin{array}{c}11-13 \\
\text { wks }\end{array}$ & $\begin{array}{l}5-13 \\
\text { wks }\end{array}$ & \\
\hline T1 & 776 & $1016 \mathrm{a}$ & $1576 a$ & $1857 \mathrm{a}$ & $2096 \mathrm{a}$ & $17.16 \mathrm{a}$ & $40.04 b$ & 20.05 & 17.07 & $23.32 \mathrm{a}$ & 0 \\
\hline T2 & 772 & $861 \mathrm{~b}$ & $1486 b$ & $1786 b$ & $2023 a$ & $6.38 \mathrm{c}$ & $44.62 \mathrm{a}$ & 21.41 & 16.97 & $22.09 \mathrm{a}$ & 0 \\
\hline T3 & 807 & $885 b$ & $1275 \mathrm{~d}$ & $1607 \mathrm{c}$ & $1848 b$ & $5.67 \mathrm{c}$ & $27.79 \mathrm{~d}$ & 23.69 & 17.22 & $18.30 \mathrm{~b}$ & 0 \\
\hline T4 & 775 & $857 \mathrm{~b}$ & $1328 \mathrm{c}$ & $1553 \mathrm{~d}$ & $1789 \mathrm{c}$ & $5.83 \mathrm{c}$ & $33.65 \mathrm{c}$ & 16.02 & 16.88 & $17.48 b$ & 0 \\
\hline T5 & 758 & $868 b$ & $1223 d$ & $1621 \mathrm{c}$ & $1860 \mathrm{c}$ & $7.86 \mathrm{~b}$ & $25.40 \mathrm{~d}$ & 28.38 & $\begin{array}{l}17.10 \\
\end{array}$ & $19.24 \mathrm{c}$ & 0 \\
\hline SEM & 7.34 & 14.95 & 32.59 & 30.79 & 31.53 & 17.35 & 25.71 & 20.58 & 17.11 & 34.71 & - \\
\hline Pvalues & 0.33 & 0.001 & 0.001 & 0.001 & 0.001 & 0.001 & 0.001 & 0.081 & 0.938 & 0.001 & - \\
\hline
\end{tabular}

Means in the same column without common superscripts are different at the level $\mathrm{P}<0.05$.

Wks: Weeks, $\quad$ MR = Mortality rate (\%).

Table 4. Carcass traits $\left(\bar{X}_{ \pm S E}\right)$ of growing NZW as affected by feed restriction at the end of experimental period.

\begin{tabular}{|l|c|c|c|c|c|c|c|}
\hline \multicolumn{1}{|c|}{ Traits } & & \multicolumn{5}{c|}{ Treatments } \\
\cline { 2 - 8 } & T1 & T2 & T3 & T4 & T5 & SEM & P \\
& & & & & & & values \\
\hline Pre-slaughter weight & 2105 & 2015 & 1852 & 1790 & 1856 & 31.83 & 0.001 \\
Hot Carcass weight, \% & 48.67 & 50.47 & 49.82 & 48.73 & 47.91 & 0.49 & 0.507 \\
Dressing weight, \% & $58.61 \mathrm{~b}$ & $60.67 \mathrm{a}$ & $59.93 \mathrm{a}$ & $58.98 \mathrm{~b}$ & $58.05 \mathrm{~b}$ & 0.52 & 0.010 \\
Forepart weight, \% & 16.60 & 16.52 & 16.50 & 16.65 & 16.42 & 0.23 & 0.979 \\
Intermediate part weight, \% & 16.52 & 16.55 & 16.45 & 16.82 & 16.35 & 0.34 & 0.453 \\
Hind part weight, \% & $23.35 \mathrm{~b}$ & $25.27 \mathrm{a}$ & $25.02 \mathrm{a}$ & $23.30 \mathrm{~b}$ & $22.87 \mathrm{~b}$ & 0.42 & 0.001 \\
Head weight, \% & 6.07 & 6.14 & 6.08 & 6.15 & 5.96 & 0.13 & 0.460 \\
Giblets weight, \% & $2.77 \mathrm{~b}$ & $2.80 \mathrm{~b}$ & $2.75 \mathrm{~b}$ & $3.02 \mathrm{a}$ & $2.93 \mathrm{a}$ & 0.09 & 0.001 \\
Liver weight, \% & 0.28 & 0.28 & 0.29 & 0.27 & 0.30 & 0.02 & 0.926 \\
Heart weight, \% & 0.82 & 0.77 & 0.80 & 0.81 & 0.82 & 0.03 & 0.912 \\
Kidney weight, \% & $2.24 \mathrm{a}$ & $1.98 \mathrm{~b}$ & $1.75 \mathrm{c}$ & $1.72 \mathrm{c}$ & $1.56 \mathrm{~d}$ & 0.12 & 0.001 \\
Abdominal fat weight, \% & $7.25 \mathrm{c}$ & $7.40 \mathrm{c}$ & $7.72 \mathrm{~b}$ & $8.16 \mathrm{a}$ & $8.08 \mathrm{a}$ & 0.22 & 0.012 \\
Empty intestine weight, \% & $15.54 \mathrm{a}$ & $14.07 \mathrm{~b}$ & $13.90 \mathrm{~b}$ & $13.17 \mathrm{c}$ & $13.04 \mathrm{c}$ & 0.38 & 0.001 \\
\hline
\end{tabular}

Means in the same raw without a common superscripts are different at the level $\mathrm{P}<0.05$.

Dressing weight, $\%=$ Hot Carcass weight, $\%+$ Giblets weight, $\%+$ Head weight, $\%$. 
weight $\%$ significantly $(\mathrm{P}<0.001)$ increased by restriction feed system as compared with ad libitum, these result in disagreement with Yakubu et al., (2007), who studied the effects of feed restriction on weaned rabbits and reported that there was no difference in the liver $\%$ as compared with ad libitum group. Abdominal fat weight $\%$, significantly $(\mathrm{P}<0.001)$ decreased by restriction feed system as compared with Ad libitum group, these results agreed with Yassein et al., (2011) and agreed partly with Bovera et al., (2008) who showed that ad libitum group gave a higher contents of scapular and perirenal fat but the high variability (high standard deviation) of this parameter fail to reach statistically significance. Empty intestine weight \%, significant $(\mathrm{P}<0.05)$ increased by restriction feed system, these results agreed with Bovera et al., (2008) who indicated that empty gastro intestinal tract on pre-slaughter live weight was significantly $(\mathrm{P}<0.01)$ higher for restriction than ad libitum feed of growing rabbit.

Other carcass traits of (weight of each forepart, intermediate part, head, heart, kidney percentages) were insignificantly affected with feed restriction system during experimental period as shown in table 4, these result in agreement with El-Speiy et al., (2015) who found that fed different restriction strategies insignificant effects on relative weight of some organs of growing rabbits.

\section{Meat quality:}

Results in Table 5 showed a significant $(\mathrm{P}<0.01)$ increase in dray matter and crude protein percentages of growing NZW with restriction feed and it's seem to increase linearly with increasing restriction period as compared to ad libitum feed. These result agreed with Lebas and Ouhayoun (1987) who found that the significant decrease in the intensively growing muscles in rabbits with feed restriction, but when rabbits were again fed ad libitum, then the protein content in meat increased. In the same trend with quantitatively restricted feed for rabbits, Xiccato (1999) showed slightly higher protein level in rabbits with restriction than in those fed ad libitum. These results in disagreement with El-Speiy et al., (2015) who indicated that feed restriction significantly $(\mathrm{P} \leq 0.01)$ decreased the meat content of dry matter and crude protein in $\mathrm{V}$-line growing rabbits at 84 days of age.

Fur significantly $(\mathrm{P}<0.01)$ decreased with restriction feed as compared by ad libitum feed, these result in accordance with Tumova et al., (2006). Moreover, the present results showed that differences in ash (\%) did not statistically differ between ad libitum or restriction feed, also rabbit 
Table 5. Meat composition and some blood parameters $(\bar{X} \pm S E)$ of growing NZW as affected by feed restriction at the end of experimental period.

\begin{tabular}{|l|c|c|c|c|c|c|c|}
\hline \multirow{2}{*}{ Traits } & \multicolumn{7}{|c|}{ Treatment groups } \\
\cline { 2 - 8 } & T1 & T2 & T3 & T4 & T5 & SEM & $\begin{array}{c}\text { P } \\
\text { values }\end{array}$ \\
\hline Dray matter,\% & $27.11 \mathrm{~d}$ & $27.94 \mathrm{c}$ & $28.19 \mathrm{c}$ & $28.72 \mathrm{~b}$ & $29.30 \mathrm{a}$ & 3.55 & 0.003 \\
Ph (after 1 hour) & 6.94 & 6.91 & 6.94 & 6.94 & 6.92 & 0.67 & 0.714 \\
Crude protein, \% & $19.38 \mathrm{~b}$ & $19.82 \mathrm{~b}$ & $20.38 \mathrm{a}$ & $20.45 \mathrm{a}$ & $20.79 \mathrm{a}$ & 2.74 & 0.023 \\
Ether extract, \% & $4.14 \mathrm{a}$ & $3.92 \mathrm{~b}$ & $3.73 \mathrm{c}$ & $3.65 \mathrm{c}$ & $3.32 \mathrm{~d}$ & 0.48 & 0.001 \\
Ash, \% & 3.57 & 3.65 & 3.73 & 3.62 & 3.77 & 0.31 & 0.703 \\
Energy value(cal/100g) & $128.72 \mathrm{a}$ & $127.32 \mathrm{~b}$ & $126.85 \mathrm{~b}$ & $126.15 \mathrm{c}$ & $124.55 \mathrm{~d}$ & 14.76 & 0.001 \\
Total protein(g/dl) & 6.03 & 6.12 & 6.07 & 6.14 & 6.11 & 0.52 & 0.942 \\
Total albumin(g/dl) & 3.90 & 3.98 & 3.82 & 3.99 & 3.93 & 0.33 & 0.556 \\
Globulin(g/dl) & 2.13 & 2.14 & 2.25 & 2.14 & 2.18 & 0.29 & 0.960 \\
AST (U/ L) & 58.50 & 57.62 & 57.50 & 57.37 & 57.62 & 5.04 & 0.989 \\
ALT U/L & 29.22 & 28.87 & 28.94 & 28.40 & 28.88 & 2.29 & 0.788 \\
Cholesterol (mg/dI) & $63.15 \mathrm{a}$ & $57.37 \mathrm{~b}$ & $51.82 \mathrm{c}$ & $49.75 \mathrm{~d}$ & $48.82 \mathrm{~d}$ & 6.20 & 0.001 \\
\hline
\end{tabular}

Means in the same raw without a common superscripts are different at the level $\mathrm{P}<0.05$.

meat $\mathrm{pH}$ after slaughter by one hour was not affected by restriction feed as shown in Table 5.

Results showed in present study agreed with El-Speiy et al., et al., (2015) who reported that meat chemical composition is an important indicator for meat quality and feed restriction is one from several factors which affect the comical composition. On the other hand, these result disagreement with Alabiso et al., (2016) who summarized that restriction feed for a 3-week post-weaning did not alter rabbit meat quality, as compared with ad libitum.

\section{Blood parameters:}

As presented in Table (5), feed restriction had no significant effect on blood parameters of (total protein, albumin, globulin, AST and ALT) of the growing rabbit, these result agreed partly with Ebeid et al., (2012) who found that no significant effect in plasma total proteins due to feed restriction for growing rabbit. On contrast, the present results disagreement 
with Rajman et al., (2006) who confirmed that feed restriction decreased plasma concentrations of total protein and albumin.

Plasma cholesterol significantly $(\mathrm{P}<0.001)$ decreased with restriction feed system, especially with increasing restriction period from 2 to 8 weeks. These result agreed with Ebeid et al., (2012) who showed that feed restriction resulted in reducing blood cholesterol, indicating lipid depletion of rabbits.

\section{Economical efficiency:}

Results in Table 6 showed a significant $(\mathrm{P}<0.01)$ improvement in economic efficiency \% of growing NZW with restriction feed and the best result was (192.98\%) which recorded with full restriction feed during all experimental period studied, while the worst one was ad libitum feed (T1, control) giving $157.10 \%$ as shown in Table 6.

These results agreed with Gidenne et al., 2003 who reported that the application of feed restriction during fattening period of rabbits, without compromising too much the growth, may be a good strategy for rabbit management, because it may decrease the feeding cost and reduce the health risk. On the other hand also, the present result in accordance with Oliveira et al., (2012) who reported that the best economic efficiency per rabbit were obtained with feed restriction in two periods (33-40 and 54-61 days of age) and from 54 to 61 days of age as compared by these obtained with rabbits feeding ad libitum and they presented better economic efficiency because during the re-feeding, priority was given to recovering the organ weight, and they added, as the muscles are better formed in high ages, they may have felt less the effects of restriction when it was applied later.

Therefore, economic efficiency \% improved with decreasing of feeding cost through using strategy of feed restriction which gave a beneficial effect of feed efficiency and weight gain (main factors used in calculation of economical efficiency \%). This result agreed with recent strategy of Gidenne et al., (2017) who reported that future possibilities for genetic selection for feed efficiency are based on improvements to the residual feed intake and it seems possible to improve feed efficiency further by reducing feed intake without affecting weight gain. Such a genetic improvement would reduce both feed input (reducing costs) and output (reducing environmental impacts). An average farm feed conversion rate of 3.0 , can be reached in the next decade for rabbit meat production. 
Table 6. Feed intake, feed conversion and economic efficiency $(\bar{X} \pm S E)$ of growing NZW as affected by feed restriction, during all experimental periods.

\begin{tabular}{|c|c|c|c|c|c|c|c|}
\hline \multirow{2}{*}{\begin{tabular}{|l|}
\multicolumn{1}{c}{ Traits } \\
Treatment \\
groups
\end{tabular}} & \multicolumn{5}{|c|}{ Daily feed intake (g.) } & \multirow{2}{*}{$\begin{array}{c}\text { FC } \\
5-13 \text { wks }\end{array}$} & \multirow{2}{*}{$\begin{array}{c}\text { EE } \\
\%\end{array}$} \\
\hline & $\begin{array}{l}5-7 \\
\text { wks }\end{array}$ & $\begin{array}{l}7-9 \\
\text { wks }\end{array}$ & $\begin{array}{l}\text { 9-11 } \\
\text { wks }\end{array}$ & $\begin{array}{c}\text { 11-13 } \\
\text { wks }\end{array}$ & $\begin{array}{l}5-13 \\
\text { wks }\end{array}$ & & \\
\hline T1 & $70.17 a$ & $133.57 \mathrm{a}$ & $142.30 \mathrm{a}$ & $153.12 \mathrm{a}$ & $129.52 a$ & $5.58 \mathrm{c}$ & $157.10 \mathrm{~d}$ \\
\hline $\mathbf{T} 2$ & $49.75 b$ & $120.20 \mathrm{~b}$ & $130.90 \mathrm{~b}$ & $137.75 b$ & $109.65 b$ & $4.96 a$ & $175.78 b$ \\
\hline T3 & $49.65 b$ & $74.76 \mathrm{c}$ & $125.55 \mathrm{c}$ & $135.25 b$ & $96.30 \mathrm{c}$ & $5.25 b$ & $165.81 \mathrm{c}$ \\
\hline T4 & $49.82 b$ & $74.88 \mathrm{c}$ & $99.76 \mathrm{~d}$ & $134.75 b$ & $89.80 \mathrm{c}$ & $5.18 b$ & $169.85 \mathrm{c}$ \\
\hline T5 & $49.75 b$ & $74.67 \mathrm{c}$ & $99.96 \mathrm{~d}$ & $123.25 \mathrm{c}$ & $87.03 \mathrm{c}$ & $4.57 \mathrm{a}$ & $186.98 \mathrm{a}$ \\
\hline SEM & 7.25 & 18.51 & 22.68 & 19.80 & 32.35 & 1.07 & 17.89 \\
\hline P values & 0.001 & 0.001 & 0.001 & 0.001 & 0.001 & 0.04 & 0.01 \\
\hline
\end{tabular}

Means in the same column without common superscripts are different at the level $\mathrm{P}<0.05$.

$\mathrm{FC}=$ Feed conversion $(\mathrm{kg}$ feed $/ \mathrm{kg}$ gain $), \mathrm{EE}, \%=$ Economic efficiency

Conclusively, feed restriction system influenced positively on the performance (specially feed and economic efficiencies), some carcass traits and meat quality of growing rabbits. On the other hand, a positive effect was observed in the $\%$ of abdominal fat and plasma cholesterol. The impact of feed restriction depends on the duration and amount for growing NZW rabbits was beneficial for those of feed and economic efficiencies under Egyptian conditions.

\section{RERFERENCES}

Agunbiade, J. A., O. A. Adeyemi., O. E. Fasina and Bagbe, S. A. (2002). Fortification of cassava peel meals in balanced diets for rabbits. Nig. J. Anim. Prod., 28: 167-173.

Alabiso, M., Di Grigoli, A., Mazza, F. and Maniaci, G. (2016). A 3week feed restriction after weaning as an alternative to a medicated diet: effects on growth, health, carcass and meat traits of rabbits of two genotypes. Animal, (Online), DOI: https://doi.org/10.1017/S1751731 $11600269 \mathrm{X}$

A. O. A. C. (1995). Association Of Analytical Chemists. Official Methods of Analysis. $16^{\text {th }}$ ed Washington, D.C, USA.

A. O. A. C. (2000). Official Methods of Analysis. $17^{\text {th }} \mathrm{ed}$. Association of Official Analytical Chemists, INC. Washington, D.C, USA.

Armstrong, W.D. and Corri, C. W. (1960). Physiological Chemistry. Laboratory Diction, $3^{\text {rd }}$ edition,P.75, Pungs Publishing Co., Minneapolis, USA. 
Bergaoui R., Kammoun M., and Ouerdiane K., (2008). Effects of feed restriction on the performance and carcass of growing rabbits. In Proc. $9^{\text {th }}$ World Rabbit Congress, 2008 June, Verona, Italy, 547-550.

Birolo, M., Trocino, A., Zuffellato, A. and Xiccato, G. (2016). Effect of feed restriction programs and slaughter age on digestive efficiency, growth performance and body composition of growing rabbits. Animal Feed Science and Technology, 222., 194-203.

Blasco, A. and Ouhayoun, J. (1996). Harmonization of criteria and terminology in rabbit meat research. World Rabbit Science., 4: 93-99.

Bovera, F., Di Meo, C., Marono, S., Vella, N. and Nizza, A. (2008). Feed restriction during summer: effect on rabbit growth performance. In: Proc. 9th World Rabbit Congress, Verona, Italy, 567-571.

Cantier, J., Vezinhet, A. and Rouvier, R. (1969). Allometrie de croissance chez le lapin (Oryctolagus cuniculus). 1. Principaux organs et tissues. Annales de biologie Animale Biochimie Biophysique, v. 9: 5-29.

Cavani, C., Bianconi, L., and Urrai, G.F. (1991). Distribuzione automatizzata e frazionata degli alimenti nel coniglio in accrescimento: 1. Influenza della modalità di distribuzione e del livello alimentare. In Proc. IX Congresso ASPA. Rome, Italy, pp. 857-864.

Di Meo C., Bovera F., Marono S., Vella N., and Nizza A. (2007). Effect of feed restriction on performance and feed digestibility in rabbits. Italian J. Anim. Sci., 6 (Suppl. 1), 765-767.

Doumas, B., Wastan, W. and Biggs, H. (1971). Albumin standard and measurements of serum albumin with bromo cresol green. Clinical Chemistry Acta., 31: 87-88.

Duncan, D. B. (1955). Multiple Range and Multiple (F-test). Biometerics. 11: $1-42$.

Ebeid, T., Tumova E., and Volek, Z. (2012). Effects of A one week intensive feed restriction in the growing rabbit: Part1. Performance and blood biochemical parameters. Proceeding $10^{\text {th }}$ World Rabbit Congress - September 3-6, Sharm El-Sheikh - Egypt, 607-611.

Eiben, C., Kurtos, K., Kenessey, A., Virag, G and Szendro, Z. (2001). Effect of different feed restrictions during rearing on reproduction performance in rabbit does. World Rabbit Science, 9: 9-14.

El-Speiy M. E., Kamel, K. I., Tag El-Din, A. E., Abd El-Hamid, A. E. and EL-Kamhawey, A. M. E.(2015). Effect of feed restriction on productive performance, carcass yield, blood pictures and relative organ weights of growing rabbits. Egypt. Poult. Sci., 35, (2): 439-454. 
Fielding, D. (1991). Rabbits. The Tropical Agriculturist. 1st Ed. Macmillan press, London/CTA.

Foubert, C., Duperray, J., Boisot, P. and Guyonvarch, A. (2008). Effect of feed restriction with or without free access to drinking water on performance of growing rabbits in healthy or epizootic rabbit enteropathy conditions. In Proc., 9th World Rabbit Congr. Verona Jun. 10-13, 207.

Gidenne, T., Feugier, A., Jehl, N., Arveux, P., Boisot, P., Briens, C., Corrent, E., Fortune, H., Montessuy, S. and Verdelhan, S. (2003). Un rationnement alimentaire quantitatif postsevrage permet de réduire la fréquence des diarrhées, sans degradation importante des performances de croissance: résultats d'une étude multi-site. In: Proc. 10èmes Journ. Rech. Cunicole, Paris, France, 29-32.

Gidenne, T., Combes, S., Feugier, A., Jehl, N., Arveux, P., Boisot, P., Briens, C., Corrent, E., Fortune, H., Montessuy, S. and Verdelhan, S. (2009). Feed restriction strategy in the growing rabbit. 2. Impact on digestive health, growth and carcass characteristics. Animal, 3, 509515.

Gidenne, T., Fortun-Lamothe, L., and Combes, S., (2011). Feed restriction strategies, implications on physiology, growth and health of the growing rabbit. In Proc. Giornate di Coniglicoltura ASIC 2011. Forli, Italy, pp. 1-19.

Gidenne T, Combes S., and Fortun-Lamothe L., (2012). Feed intake limitation strategies for the growing rabbit: effect on feeding behavior, welfare, performance, digestive physiology and health: a review. Animal, in press (first view).

Gidenne, T. Garreau, H., Drouilhet, L., Aubert, C. and Maertens, L. (2017). Improving feed efficiency in rabbit production, a review on nutritional, technico-economical, genetic and environmental aspects. Animal Feed Science and Technology, 225., 109-122.

Govaerts, T.; Room, G.; and Buyse, J. (2000). Early and temporary quantitative food restriction of broiler chickens. 2. Effect on allometric growth and growth hormone secretion. British Poultry Science, 41, p.355-362.

Heady, E. O. and Jensen, H. R. (1954). Farm Management Economics. Prentice.-Hall, Inc. Englewood Cliffs, N.J.

Lebas, F. and Ouhayoun, J. (1987). Effect of dietary protein level, housing conditions and season on growth and slaughter traits of rabbits. Annales de Zootechnie, 36: 427-432. 
Ledin, I. (1984). Effect of restricted feeding and realimentation on compensatory growth, carcass composition and organ growth in rabbit. Annales de Zootechinie, v. 33 p. 33-50.

Maertens, L., (2009). Possibilities to reduce the feed conversion in rabbit production. In Proc. Giornate di Coniglicoltura ASIC 2009. Forli, Italy, $p p .1-10$.

N. R. C. (1977). National Research Council: Nutrient Requirements of Rabbits. $2^{\text {nd }}$ Revised Edition, National Academy of Sciences, Washington, DC, USA.

Oliveira, M. C., Silva, R. P., Araujo, L. S., Silva, V. R., Bento, E. A. and Silva, D. M. (2012). Effect of feed restriction on performance of growing rabbits. Revista Brasileira de Zootecnia., V. 41, (6): 1463-1467.

Ouhayoun, J., Poujardieu, B., and Delmas, D., (1986). Influence des conditions d'élevage et du rationnement sur la vitesse de croissance du lapin entre 11 et 20 semaines. 2 - Composition corporelle. In Proc. 4èmes Journées de la Recherche Cunicole. Paris, France, Communication No. 24.

Rajman, M., Juráni, M., Lamošová, D., Máčajová, M., Sedlačková, M., Košt'ál, L., Ježová, D. and Výboh, P. (2006). The effects of feed restriction on plasma biochemistry in growing meat type chickens (Gallus gallus). Comp. Biochem. Physiol., 145 A, 363-371.

Rommers, J.M., Kemp, B., Meijerhof, R., Noordhuizen, J.P.T.M. and Kemp, B. (2001). Effect of different feeding levels during rearing and age at first insemination on body development, body composition and puberty characteristics of rabbit does. World Rabbit Science, 9:101108.

Sendcor, G. W. and Cochran, W. G. (1982). Statistical Methods $\mathbf{2}^{\text {nd }}$ Edition. Lowa University., press. Ames., Iowa.

SPSS (2014). Statistics Users Guide, Version 14, SPSS Inc., USA.

Tumova, E., Skrivan, M., Skrivanova, V. and Kacerovska, L. (2002). Effect of early feed restriction on growth in broiler chickens, turkeys and rabbits. Czech J. Anim. Sci., 47, $418-428$.

Tumova, E., Skrivanova, V. and Skrivan, M. (2003). Effect of restricted feeding time and quantitative restriction in growing rabbits. Arch. Geflungelkde.

Tumova, E., Skrivanova, V., Zita, L., Skrivan, M. and Fuclkova, A. (2004). The effect of restriction on digestibility of nutrients, organ growth and blood picture in broiler rabbits. In Proc.: 8th World Rabbit Congress, Puebla, September 7 -10, Mexico, 1008-1014. 
Tumova, E., Zita, L., Skrivanova, V., Fuclkova, A., Skrivan, M. and Buresova, M. (2007). Digestibility of nutrients, organ development and blood picture in restricted and ad libitum fed broiler rabbits. Arch. Geflügelk., 71, 6-12.

Winton, A. L. and Winton, K. B. (1958). Okaloffs Magnesium Oxide Distillation Volumetric Method. The Analysis of Foods, pp. 848, John Wiley, New York, Chapman and Hall, Ltd. London.

Xiccato, G. (1999). Feeding and meat quality in rabbits: A review. World Rabbit Science, 7: 75-86.

Yakubu, A., Salako, A. E., Ladokun, A. O., Adua, M. M. and Bature, T. U. K. (2007). Effects of feed restriction on performance, carcass yield, relative organ weights and some linear body measurements of weaner rabbits. Pakistan J. Nutr., 6, 391- 396.

Yassein, S. A., Abdel-Aziem, S. H., El-Mallah, G. M. and Maghraby, N. A. (2011). Response of growing rabbits to feed restriction and some additives on performance, carcass and hepatic gene expression under Egyptian summer conditions. Journal of Agricultural Science, 3, (2): 45-55.

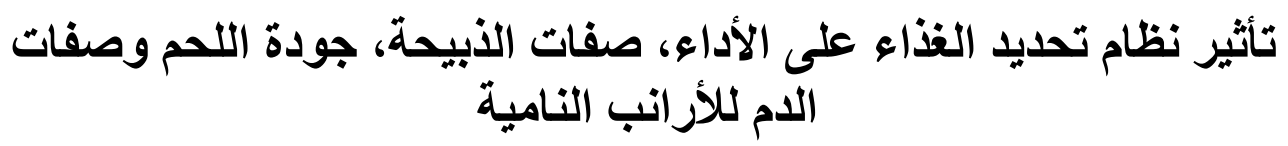

$$
\begin{aligned}
& \text { ضياء السيد أبوقاسم } \\
& \text { قسم الدو اجن ، كلية الزبو اعة اعة ، جامعة الزقازيق، الزقازيق، مصر }
\end{aligned}
$$

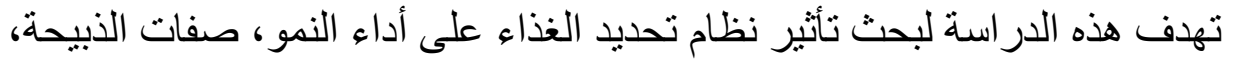

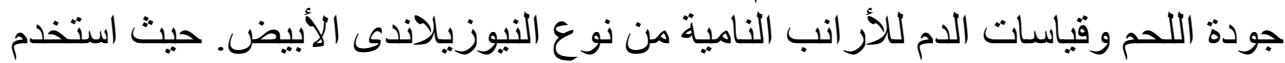

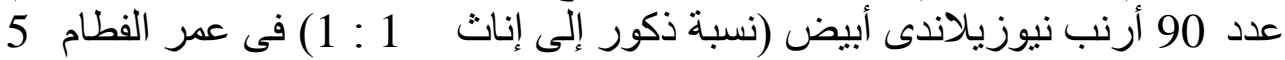

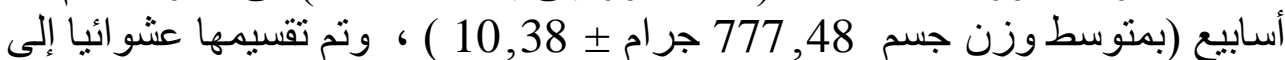

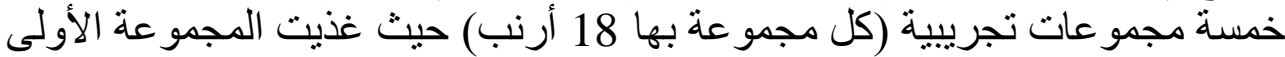

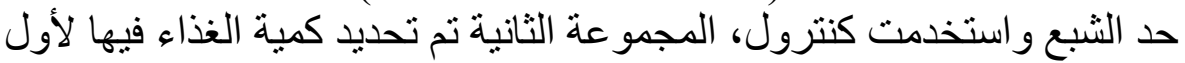

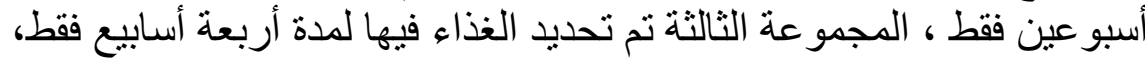

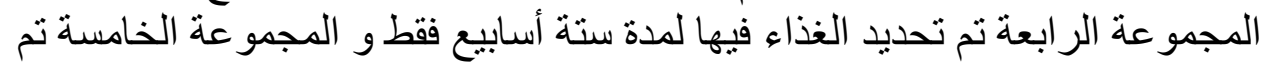

$$
\begin{aligned}
& \text { تحديد الغذاء فيها طول مدة التجربة (8 أسابيع). }
\end{aligned}
$$




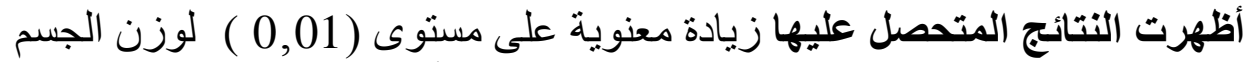

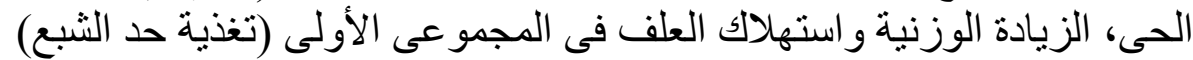

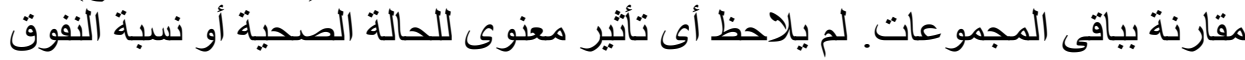

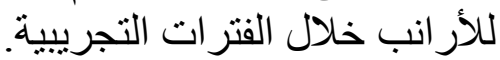

انخفض دهن البطن معنويا على مستوى ( 0,05) للأر انب محددة الغذاء مقارنة

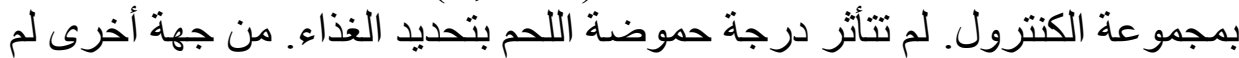
تتأثر معنويا قياسات الدم المدروسة نتيجة المعاملة.

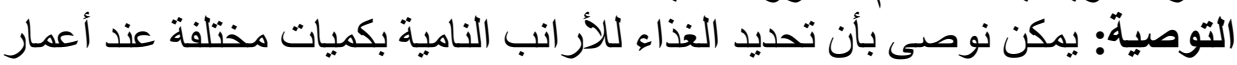

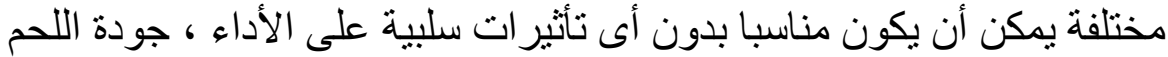

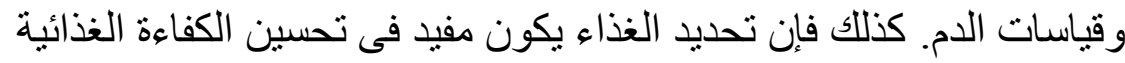

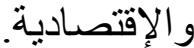

